\title{
Theological Education and Society/Social Sciences - the Case of Practical Theology
}

\author{
Khee-Vun Lin \\ \{kheevun@gmail.com\} \\ Anglican Training Institute Sabah ${ }^{1}$
}

\begin{abstract}
Abatract. This essay considers the relationship between theological education and social sciences.The contributions of social sciences in theological education are discussed. Practical theology is used as a showcaseof theological educationrevitalized by social sciences.
\end{abstract}

Keywords: Teological Education, Society Science, Practical Theology

\section{Introduction}

\subsection{Theological Education}

Theological education, strictly, is the process where holistic Christian living is formed. Its starting point is the understanding of "theology" as an all-encompassing knowledge of God and the corresponding responses involved.[1]It involves experiences, thinking theologically, spirituality, and contextualization, apart from having deep knowledge of the Christian traditions and doctrines. Theological education should be relevant and accessible to common believers, instead of being limited within the boundaries of the academia.

\subsection{The Significance of Theological Education in the Global Perspective}

Theological educationthat involves every Christians holistically would impact the society. Theologically educated Christians would become communicative in their social relations, oftentaking the stance of challenging the status quo.[1]Through them,theological educationwould affect the spiritual, ethical, social, political, and even economic contour of the society. Further, the mission of the Christian Church today is perceived as multicentric, crossing borders, cultures, and languages.[2, p. 235] Subsequently, theological education of a certain context may affect any other part of the world.No more would theological education be directed from "the West to the rest."In fact, the dwindling and contracting church of the West awaits the churches of Asia, Africa, and Latin America to take the lead.[2, p. 238] This is vital in view of the state of theological academy in the West, where secularism, career interests, and business profitshave taken control.[2, p. 239] In other words, theological education's global nature is not only a growing reality but a necessity.

\subsection{Shortcomings in Theological Education}

Sadly, although theological educationshould involve educating Christians holistically, its content and curriculum haveoften failed to engage with the current situation in the world. Theological education used to play a key role in education, assuming a pivotal role in the 
Western society. After the Enlightenment, theological educationhas gradually moved away from being a spiritual discipline of relating to God and the world, into academic exercises, focusing on scholarship fashioned after the philosophical tenets and methods of Enlightenment. A prime facet of the Enlightenment-influenced theological education is the division of theory and practice, modeled after the division between natural science and applied science.[3, pp. 231235]Consequently, theological educationloses its holistic nature, leaving theological scholarship in its academic ivory tower, with little interaction and use for ordinary Christians and church ministry even though these are the very people whom theological educationexists for.[3, pp. 231-235]. Further departmentalization saw the subdivision of theological education into encyclopedic streams of biblical studies, theology, church history and "practical theology."[3, pp. 231-235] theological education subscribes to a defective understanding of "practical theology" that only studies and applies "theological theory" without any serious consideration of the sociopolitical and cultural contexts. Yet today, most acknowledge that "Theology is practical only by applying God's revelation as directly and purely as possible to the concrete situation of life."[5, pp. 5-6] Theology should begin with understanding the concrete situation of life instead of simply following the encyclopedic model. This is where the weakness of a departmentalized, encyclopedic theological educationlies.

\section{Social Sciences And Their Relation To Theological Education}

Fundamentally, social sciences might have a secular underpinning which is antithetical to Christianity.[6] Yet, at the level of practicality, social sciences are often welcome in Christian ministry and theological education.[7]In theological education, both quantitative and qualitative researches are employed to yield insights to church ministry patterns and other information.

\subsection{Social Sciences' Relation to the Church}

Social sciences'interaction with the Church is most prominent in the field of missiology and church ministry. Missionaries rely on social sciences to help them understand foreign cultures and societies they encounter. Similarly, pastors use sociology tools, such as survey and other forms of quantitative research to study their congregations. [8]Both of these fields require an accurate understanding of the people and culture in a specific sociopolitical context. Thus, as social sciences developed in the early and mid-twentieth century, the practitioners and scholars of these fields began to adopt useful tools and concepts in social sciences for their benefit. Noticeably, qualitative research, often in the form of ethnography is today an accepted or even essential methodology for the study of culture and people in a given church ministry context.[9]

\subsection{Social Sciences' Contributions to Theological Education}

As missiology and church ministryinteract with social sciences, their education has also undergone changes. In missiology classes today, students are exposed to various social sciences concepts and tools which help them to understand their mission context and to communicate better.For example, anthropology has informed generations of Christian missionaries the knowledge and skills they need for intercultural mission, so it has become a key component in missiology education.[10]In church practical ministry, the study of ministry context, much like 
the study of mission context, requires the aid of social sciences.Ethnography has been incorporated in the study of congregation, and becomes an integral part in some ministry trainings.[11] Political and public theologies which require an understanding of sociology and political science, amongst others, are taught beyond engaging with classical "Christian" text.For example, apart from Augustine of Hippo's thoughts, one would need to engage critically with the political thoughts of Karl Marx and Thomas Hobbs.On the study of human nature,psychology is accepted as a field which can contribute to theological education. In fact, psychology was included in theological education soon after the Second World War.[7, p. 286]Today, the well-established School of Intercultural Studies and School of Psychology at FullerTheological Seminary are examplesof social sciences' incorporation in theological education.

\section{The Case Of Practical Theology}

The use and significance of social science can be demonstrated through practical theology and the theological education which associated to it.Practical theology is a "critical, theological reflection on the practices of the Church as they interact with the practices of the world with a view to ensuring faithful participation in the continuing mission of the triune God." $[9, \mathrm{Ch} .1] \mathrm{The}$ study and understanding of human experiences, their underlying motives, worldview, and social interactions are vital to practical theology.[9, Ch. 1, 2], [11, pp. 38-40] Practical theology combines the interpretation of doctrine and tradition, biblical studies that interpret the Bible, and the interpretation of the context,to formulate "theological treaties" and solutions. [9, Ch. 1] The "interpretation of the practices of church and world" is seen as "an ongoing source of theological interpretation and understanding." $[9, \mathrm{Ch} .1] \mathrm{In}$ other words, practical theology relies on an understanding of the context.

\subsection{How Practical Theology utilizes Social Sciences}

The need to interpret the context attracts the use of social sciences in practical theology. As practical theology begins with practical concerns, it usually begins with the descriptiveempirical and the interpretive tasks.[3] These are often informed and all carried out through the use of social sciences tools.[11] These tasks can be traced to Clifford Geertz's "thick description," one of the hallmarks of cultural anthropology. Often, interpretive methods are preferred over more "scientific" or inductive methods. Qualitative research is often a better methodology than quantitative research to understand a context.[9]This is crucial in this postmodern and globalized age where different groups or context may hold very different worldview that animates their respective culture and "narratives." More so, in the polemical political climate today, an interpretive task such as ethnography will prove to be more effective to unravel the power structure in any given social context.

\subsection{Resolving Present Shortcomings of Theological Education}

Due the development of theological education described earlier, practical theology has been relegated to a lower status compared to the purportedly more prestigious subjects such as systematic theology that focuses on certain "classical" or "pure" theology. The role of interpreting the context is often rejected. The studies on the classical doctrines are regarded as 
sufficient. Today, the shortcomings of such theological education are obvious. Ministry issues that involvepolitics and social ethics cannot be answered via simply combining the studies of various confessional doctrines or biblical studies alone. Unless the theological students are taught to interpret the context involved, they are unable to interpret these issues effectively, lest formulate relevant theological treatise. For such issues, experts in either biblical studies or systematic theology will need extra knowledge and expertise before they can formulate a stand or viewpoint. The problem is beyond a lack of interaction between different expertise, but a lacking in theological education where curriculums are not designed to enable the students to interpret the context. The outcome of such theological educationbecomes irrelevant to the society.[3, p. 220]. The use of social sciences provides a solution, as in the case of practical theology. Practical theology rediscovers a "missing dimension" of the theological education, which is the interpretation of context.[9, Ch. 1,2]As social sciences play a key role in the interpretation of context, they are vital in practical theology and should be an integral part oftheological education. For only through integrating the study of the context, theological reflection, and application, will theology be relevant to everyone and restored to its fullest meaning.

\section{References}

[1] B. C. Farr, "On Being Theologically Educated: Ten Key Characteristics," Transformation, vol. 29, no. 4, pp. 260-276, 2012.

[2] A. F. Walls, "World Christianity, Theological Education and Scholarship," Transformation, vol. 28, no. 4, pp. 235-240, Oct. 2011.

[3] R. R. Osmer, Practical Theology: An Introduction. Grand Rapids: Eerdmans, 2008.

[4] F. A. Oborji, "Contemporary Missiology in Theological Education: Origins and New Perspectives," Missiology, vol. 34, no. 3, pp. 383-397, Jul. 2006.

[5] D. Browning, Fundamental Practical Theology, Revised edition. Minneapolis: Fortress Press, 1995.

[6] Milbank, Theology and Social Theory: Beyond Secular Reason 2nd edition by Milbank, John (2006) Paperback, 2 edition. Wiley-Blackwell,2006.

[7] R. L. Montgomery, "Can Missiology Incorporate More of the Social Sciences?," Missiology, vol. 40, no. 3, pp. 281-292, Jul. 2012.

[8] N. Ammerman, J. Carroll, C. Dudley, and W. McKinney, Eds., Studying Congregations: A New Handbook. Nashville: Abingdon Press, 1998.

[9] J. Swinton and H. Mowat, Practical Theology and Qualitative Research, Kindle. London: SCM Press, 2011

[10] C. H. Kraft, Anthropology for Christian Witness. Maryknoll, N.Y: Orbis Books, 1997.

[11] M. C. Moschella, Ethnography as a Pastoral Practice. Cleveland, OH: The Pilgrim Press, 2008. 